A N N A L E S

UNIVERSITATIS MARIAE CURIE-SKŁODOWSKA

LUBLIN - POLONIA

VOL. XXXIV

SECTIO FF

$1-2016$

ANNA SADKOWSKA

Uniwersytet Marii Curie-Skłodowskiej

\title{
The Translator Is Hitting the Road - on the Untranslatability of Culture
}

Tłumacz rusza w drogę - o nieprzetłumaczalności kultury

\section{TRANSLATING CULTURE AND CULTURE-BOUND CONCEPTS}

Before the 1980s, the focus of translation studies was centred mainly on the formalist approach to translation. Around that time, scholars and theorists began to realise that the process of translation involves more than a mere replacement of one language system with another. As Susan Bassnett claims, the "cultural turn" in linguistics and translation was possible due to a couple of milestones such as, among others, the emergence of corpus linguistics, with its interest in actual examples of discourse in its natural circumstances, or discourse analysis, which focused on discourse and language as embedded in a social context (Bassnett 2007: 13-15). The reason why the relationship between language and culture was neglected before the 1980s could be the traditional but outmoded separation of branches in translation studies that were still in use at many universities of that time. Culture was only touched upon in literary studies, while it was disregarded by linguists, whose area of interest was language exclusively (Lambert 2006: 165). Since the cultural turn, the translation process has been perceived more as the transfer of meaning than the transfer of language system. For that reason it is believed that words, even though they can of course be perceived as purely linguistic elements, cannot be translated otherwise than in the context in which they are used by language users. As André Lefevere (1992: 14) states, "Translations are not made in a vacuum. Translators function in a given culture at a given time." Translation is thus more of an intercultural transfer than simply linguistic 
transfer, but, as Bassnett underlines "separating language from culture is like the old debate about which came first - the chicken or the egg. Language is embedded in culture [...] for the two are inseparable" (Bassnett 2007: 23).

Notwithstanding the cultural "revolution", theorists still fail to provide a single, accurate definition of what culture actually is. A simple statement that culture is a system, an ensemble of shared values, beliefs, traditions and history which are created by and govern a particular group of people is an understatement at best. However, the question arises if defining culture in such an accurate manner is really indispensable. It would seem not, since the majority of language users is able to recognise a reference to culture in a given text or utterance without being able to provide a precise definition of the concept. These references are known in the world of translation studies as culture-bound concepts. It is argued that "every language has words denoting concepts and things that another language has not considered worth mentioning or that are absent from the life or consciousness of the other nation" (Leemets 1992: 475). Those include names of some dishes, festivities, clothes, music, arts and others. Alicja Pisarska and Teresa Tomaszkiewicz (1996: 175) add to those the concepts which are present in both the source and the target culture, but the symbolism of which differs. They cite as an example the concept of snow which has a different connotation to, for instance, an Inuk, who lives in a region covered with so much snow that his people invented hundreds of various words to refer to it, an African, who has probably never seen it, or an Englishman, for whom the snowfall reminds of the periodicity of seasons. Due to the incongruities between cultures, the translation of culture-bound concepts may pose a difficulty to translators, as one-to-one equivalent hardly ever exists.

Alejandra Patricia Karamanian (2002) explains the process of translating culture-bound concepts as consisting in de-coding a particular cultural concept and the message behind it, converting (re-coding) that message into the cultural code of the receiver's reality and implementing (en-coding) this code into the target language. Similarly, according to Eugene Nida and Charles Taber (1969), cultural translation is "a translation in which the content of the message is changed to conform to the receptor culture in some way, and/or in which information is introduced which is not linguistically implicit in the original" (ibidem: 199). A translated message is thus transposed into the reality of the target language users, some adaptation being made in the process. However, as Krzysztof Hejwowski (2004) observes, "it is unrealistic to expect a "similar response" in the case of culturebound items, as what is familiar and domestic to the SL readers will be alien and exotic to the TL readers" (ibidem: 129). Even though the readers may comprehend the concept, the associations it evokes will be different. Thus preserving the culture-bound concept in question in the target language might, at the most, produce confusion or even no response at all. Sometimes the concept might not even be recognised as cultural by the target audience. On the other hand, adaptation is also 
questionable since when taken to extremes, it might pose a threat of overly domesticating the text. This may further result in expunging source culture references from the translated text, which is highly undesirable in the case of texts intending to show the cultural otherness or the success of which is based on their presence.

In translation practice, the translator has more solutions at his or her disposal than the two aforementioned poles for dealing with culture-bound concepts. Jan Pedersen (2005) considers them to be one of "translation crisis points" and describes them as follows:

Extralinguistic Culture-bound Reference (ECR) is defined as reference that is attempted by means of any culture-bound linguistic expression, which refers to an extralinguistic entity or process, and which is assumed to have a discourse referent that is identifiable to a relevant audience as this referent is within the encyclopedic knowledge of this audience (Pedersen 2005: 2).

Pedersen proposes seven techniques for translating ECRs. He begins with official equivalent, that is a standard, recognised translation of the cultural reference, arguing that in this particular case the reference is not a translational problem as such since there is a "pre-fabricated" solution to it. The next one, retention, consists in transferring the concept as it is, with no additions, the only adjustments being allowed in spelling. The use of this technique is however questionable due to the fact that the target audience, devoid of any guidance from the part of the translator, may not understand the concept and, consequently, even the whole text. Next, he proposes specification which is the transfer of the ECR in its unchanged form concurrently employing some additional information through explicitation, that is the expansion of the concept by, for instance, spelling out acronyms, or addition, consisting in adding guidance for the target reader that is not implicit in the source text. It is, however, space-consuming and not recommended for audiovisual translation. Direct translation, or in other words a literal translation, can be a viable translation solution for common or well-recognised proper names, as it neither entails a change in meaning, nor involves any additions for the target readers. Pedersen also enumerates generalisation, consisting in replacing a specific concept by a more general term, as a translation technique for ECRs. Unfortunately, it is often perceived as undertranslation and a considerable simplification, or even impoverishment, of the cultural concept. Substitution, in turn, is subdivided by Pedersen into two categories: cultural substitution, that is erasing a source culture reference and substituting it with a reference to the target culture, and paraphrase. Cultural substitution is however criticised as it may evoke undesirable associations in target readers' minds and cause the loss of numerous source culture connotations. Paraphrase is usually lengthy and for that reason cannot be used for recurring concepts, albeit the resulting translation is relatively precise. Pedersen 
further subdivides paraphrases into paraphrases with sense transfer (those which transfer the meaning of the source culture reference but abandon the said reference) and situational paraphrases (those which remove the ECR and its sense completely while replacing it with anything that conforms with the contextual situation of the text). The latter can be also regarded by some linguists as omission, or as Pedersen defines it - substituting a given cultural reference with nothing. Omitting a cultural reference is a very debatable translation technique and is rather considered to be a last resort, admissible in only few circumstances of extremely problematic and negligible concepts. It also raises the question of qualifications of the translator who is often condemned by the circle of other translators and, eventually, target text readers for resorting to such an ultimate technique (confer: Pedersen 2005: 2-9; Hejwowski 2004: 136-143).

\section{HUMOUR AS A CULTURE-SPECIFIC PHENOMENON}

As with culture, the endeavours of language scholars to provide a single, precise and exhaustive definition of humour have failed, as they were focusing on only some particular aspects of the concept and neglecting the others. Therefore, they now rather choose to describe humour more broadly as those utterances or situations "the perlocutionary effect of which is laughter" (Kerbrat-Orecchioni 1981 as cit. in Kostovčík 2009: 176). This definition not only easily encompasses numerous types of humour, but it also emphasises their ultimate outcome - laughter. Even though humour can be universal, recognised in more than one country or society, the majority of its instances is highly culture-dependant and embedded in the reality in which a specific group of people lives. Regarded as untranslatable for a long time and still viewed as arguably one of the most challenging phenomena in translation, humour has now been a subject of research in the domain of translation for a couple of decades.

The most basic division of humour includes two categories: (i) verbal humour, that is every occurrence of a humorous element which is found in utterances, both oral and written, and (ii) visual humour, that is one that can be seen and the humorous quality of which is a product of situational goings-on. Debra Raphaelson-West (1989: 130) proposes a bit different division based on the translation difficulty. These are, in the order from the easiest to the most difficult to translate: universal humour, culture-specific humour and language-specific humour (as puns or wordplays). Patrick Zabalbeascoa (1996 as cit. in Kostovčík 2009: 177), in turn, suggests a more detailed division of humorous utterances in his discussion on the translation of jokes in audiovisual materials. He enumerates seven types of jokes: (i) international and bi-national jokes, (ii) those referring to national institutions, (iii) those pertaining to the community's sense of humour, (iv) language-dependent jokes, (v) visual jokes, (vi) aural jokes, which consist of 
non-translatable noises and onomatopoeic words, and (vii) complex jokes, which combine two or more of the aforementioned categories. As the subject of this article revolves around cultural humour, further discussion will only concern the first three distinguished by Zabalbeascoa.

When it comes to translating cultural humour specifically, the majority of techniques proposed by scholars and practitioners overlap with those enumerated for the translation of culture-bound concepts. Since "all jokes are expressive of the social situation in which they occur" (Tisgam 2009: 81), the instances of cultural humour almost always allude to people, customs, historical or social events or literary texts of a given culture. Notwithstanding the chosen technique, the most prominent rule governing the translation of humour is that when faced with a problematic element, "the actual semantic meaning of any instance of verbal humour is secondary to its primary intention to be humorous" (Kostovčík 2009: 176). Therefore, when the translation of that element is linguistically possible through, for instance, literal translation, whilst running the risk of being misunderstood or not understood at all, the humorous effect takes precedence in translation over linguistic form or even the cultural connotation of that element.

\section{TRANSLATING THE UNTRANSLATABLE AND THE UNTRANSLATABILITY OF CULTURE}

In 1929, Edward Sapir, an American anthropologist and linguist, asserted that "no two languages are ever sufficiently similar to be considered as representing the same social reality" (as cit. in Korzeniowska \& Kuhiwczak 1998: 28). It can be thus inferred that the translated text will never be an exact reflection of the source language text. John Catford (1965: 36) concurs with that assertion by acknowledging that "since every language is formally sui generis and formal correspondence is, at best, a rough approximation, it is clear that the formal meaning of SL items and TL items can rarely be the same." For that reason, the translators often find some concepts in the source language impossible to translate, or "untranslatable," and thus are unable to produce an equivalent notion in the target language. Untranslatability, as Catford puts it, happens "when it is impossible to build functionally relevant features of the situation into the contextual meaning of the TL text" (ibidem: 94). It is thus a feature of a source language word, expression, phrase, text or any other utterance, for which no exact equivalent in the target language can be provided.

In his book A Linguistic Theory of Translation, Catford (confer 1965: 93103) elaborates further on the issue and distinguishes two categories of untranslatability: linguistic and cultural. Linguistic untranslatability occurs due to formal linguistic incongruities between the character and structure of the source language and the target language. On the other hand, when a given "situational feature", 
that is a given concept functioning in the source culture is entirely absent from the culture of the target readership, we talk about cultural untranslatability.

Due to the complicated relationship between language and culture in linguistic studies, the dichotomy proposed by Catford for the issue of untranslatability has been subjected to much criticism. The most important argument against his division is the thesis that "languages are inseparable from their cultures" (Cymbalista 2003: 22). As Jingjing Cui explains, "Culture includes and affects language, it is this ground from which language grows and develops. All languages are the product of the culture as well as of the nation" (2012: 827). According to this theory, every occurrence of linguistic untranslatability essentially concerns the problem of untranslatability of cultural disparities between distinct societies. If culture includes language, then every instance of linguistic untranslatability is, concurrently, an occurrence of cultural untranslatability and the division is redundant. For others, language is not as much a part of culture, but rather a vehicle of cultural specificity (Hatim \& Mason 1989: 237). Language and culture are thus autonomous but, simultaneously, closely related and intertwined. Based on this perspective, if a given utterance is linguistically untranslatable, it may or may not be, at the same time, culturally untranslatable. Teresa Bałuk-Ulewiczowa (2002) suggests that linguistic barriers are often only superficial but surmountable obstacles for the process of translation, the problems originating in reality from the mere essence of translation, that is the distinctiveness of cultures on the level of collective experiences of societies which are parts of these cultures (ibidem: 16). Therefore, it can be inferred that differences between languages on the strictly formal level do not preclude translation. The meaning of what is being expressed in the source language, albeit culturally-embedded, can still be transposed into the target language. Catford himself is also critical towards the division into linguistic and cultural untranslatability since, in many instances,

what renders 'culturally untranslatable' texts 'untranslatable' is the fact that the use in the TL text of any approximate translation equivalent produces an unusual collocation in the TL. To talk of 'cultural untranslatability' may be just another way of talking about collocational untranslatability: the impossibility of finding an equivalent collocation in the TL. And this would be a type of linguistic untranslatability (Catford 1965: 101).

Despite the disagreement among theorists about whether the linguistic/cultural untranslatability dichotomy is reasonable in the light of the relationship between language and culture, it seems to be applicable in translation practice when the problem of untranslatability occurs.

Notwithstanding the foregoing deliberations, yet another discussion pertaining to the concept is being held at the same time - the one concerning approaches to untranslatability. Moruwawon Samuel and Kolawole Samuel (2007) name 
three most prominent ones: universalist, monadist and deconstructionist. According to universalists, every utterance or text is translatable due to the existence of "linguistic universals" in languages and the capability of every linguistic society to express their own and even foreign culture through the use of language. Therefore, everything that can be expressed in one language can undoubtedly be expressed in any other language. The translatability of a given item depends only on the linguistic and extra-linguistic competence of the translator who is the sole person responsible for the potential failure in rendering the source text. Monadists, in turn, perceive each linguistic community as independent and having its own, distinct view on and interpretation of the world. It can be inferred that, since they do not share linguistic systems either, each community creates specific and unparalleled concepts which reflect the reality they live in and this indicates the existence of untranslatability. Due to the lack of one-to-one correspondence between languages and cultures, the meaning of the source text can never be perfectly reflected in the target text, implying that there is no such thing as translation but only adaptation of the given text. Finally, the deconstructionist approach proclaims that translation is not a mere transfer of the source message into the target language, but rather a "re-writing" of the source text and has influence on its reception and perception. For deconstructionists the target language does not reflect, but modifies the source text and its reality, whereas the translated text gains its own identity. Since the target text does not represent the meaning of the source text, losses are unavoidable and thus untranslatability may appear (confer 2007: 375-379).

When considering the aforementioned approaches to untranslatability, one cannot help but ponder the issue of its absoluteness. Can everything be translated (universalists) or is nothing, in reality, translatable (monadists)? Is untranslatability truly an insurmountable barrier precluding effective transfer of the meaning of a text to another language? In her article Beyond cognizance: fields of absolute untranslatability, Bałuk-Ulewiczowa purports that absolute or, as she also calls it, "inherent" untranslatability exists and that "some problems in translation are not relative and negotiable" (2000: 173). She provides the following definition:

Absolute untranslatability occurs whenever a text is presented for translation the full comprehension of which by its source-language recipients requires the application of extratextual subjective information or, more generally, extra-textual emotional experience which is inaccessible to the recipients of the target language for the translation. Ultimately absolute untranslatability involves irreconcilable differences of collective social identity between the group of recipients of the original text in its source language and the target group of recipients of the translation in the target language. These irreconcilable differences of recipients' communal identity create insurmountable, absolute barriers preventing the full transfer of the original message in the translation - however good its linguistic quality (ibidem: 173f). 
Therefore, Bałuk-Ulewiczowa relates absolute untranslatability with what Catford calls cultural untranslatability. Collective consciousness, group identity and experience of the source language audience, which were shaped in given historical circumstances, are not parallel in any way to those of the target language audience. Living in a different socio-historical space, the latter were not able to create analogous sociolinguistic references in their own culture. The arising translation problems are therefore irresolvable since the meaning of the target text and the source text will never be the same. Peter Newmark (1988: 79), on the other hand, purports that to claim of untranslatability as absolute is absurd since translators may always resort to different translation techniques, such as, for example, a footnote or a list of partial synonyms, which, as a whole, can convey the meaning of the untranslatable concept. Catford agrees with him and claims that "SL texts and items are more or less translatable rather than absolutely translatable or untranslatable" (1965: 93), inclining to the view that untranslatability, or translatability, is gradable. Thus, everything can be, to some degree, translated, even though it leads to the conclusion that translating a given cultural concept may more often than not entail a loss of some kind. Yet, as the task of the translator is to transfer the meaning of the source text into the target language, they cannot simply designate a given translation problem as "untranslatable" and hold on a white flag. While translators may be aware of the fact that absolute untranslatability may or does exist, in the course of their professional career they usually choose to ignore it since they, as professional translators, cannot afford the luxury of agreeing with the notion. Whatever their personal standpoint on the matter, for the sake of the target readership, they must be inclined to believe that everything is, to at least some degree, translatable. They should attempt to produce the most satisfactory translation, bearing in mind that whilst there will always be some loss, the fact that they make the effort is already a gain for the target reader. For if they succumb to the idea of absolute untranslatability, they forfeit their job as translators at the very beginning.

\section{GRADATION ATTEMPT}

Most divisions of categories for different linguistic phenomena focus mainly on their characteristic features and group them accordingly. Those divisions are usually brought forward by scholars and theorists of translation and though are essential in an effective translation process, they often miss the additional focus on the prospective result of the process as recognised by the author of the translation. This perspective could bring an interesting insight into approaching translation problems in the translator's practice.

The American TV sitcom The Big Bang Theory and its Polish rendition was employed here as the source of examples which perfectly illustrate the proposed 
categorisation of translation problems, as the series is rife with instances of highly cultural humour.

The proposed classification is based on the gradation of untranslatability in the eyes of the translator and includes three categories: culture bumps, complex linguistic hurdles and culture clashes.

Culture bumps are those occurrences of culture-bound concepts which may pose some challenge in translation but do not preclude the translator from finding a viable answer to the problem. They can be referred to as "bumps" since they bring to mind the bumps on the road which the translator encounters on his journey to identify a perfect translational solution. Although not straightforward to transpose into the target language reality, their cultural characteristic may somehow be preserved in the translation of such humorous utterances. The target recipient is thus not deprived of the two most important elements - cultural reference and humorous effect. A good example of such "bump" can be a dialogue between an overly obese Mrs Wolowitz and her son Howard from episode four of The Big Bang Theory's fourth season.

\section{S04E04}

Mrs Wolowitz: Howard, have you seen my girdle?

Howard: $\quad$ No, Ma!

Mrs Wolowitz: I can't find it, and I'm late for my Weight Watchers meeting!

Howard: Maybe it committed suicide! Leave me alone!

...

Mrs Wolowitz: Howard, I found my girdle! It was in the dryer!

Howard: Great, Ma!

Mrs Wolowitz: I think it shrunk! I'm spilling out like the Pillsbury Doughboy here!

The cultural concept refers to Pillsbury Doughboy - the mascot of the Pillsbury Company which appears in their advertisements of baking and refrigerated products since 1965. It is a plump boy made from dough, with a scarf and a chef's hat on his head (Bellis, n.d.). Due to his looks, Pillsbury Doughboy creates a humorous effect in the utterance when contrasted with the appearance of Howard's mother (as described by her son) - an extremely obese woman, especially in the arms, with voracious appetite, trying in vain to lose weight with the Weight Watchers group. Thus, when she tries to fit in the shrunk girdle, she ends up spilling from it like the chubby Pillsbury Doughboy. Since the brand is not known to the Polish audience and the name Pillsbury Doughboy does not connote anything to the Polish viewer, the concept poses a potential challenge for the translator. 
Cultural untranslatability, though, can be easily avoided by employing the technique of cultural substitution. It is virtually impossible to retain the cultural reference to Pillsbury Doughboy in the dialogue so that it would be understandable for the Polish viewer, however, it is relatively easy to preserve the humorous effect of the utterance by replacing "Pillsbury Doughboy" with "ludzik Michelin" (Eng. Michelin Man). The Michelin Man, officially known as Bibendum, is the mascot of the tyre manufacturer Michelin, recognisable by its appearance of a stack of tyres which look like belly rolls in an obese person. Although the reference does not originate from the Polish culture, the mascot is commonly known in Poland and can be easily associated with Mrs Wolowitz's appearance, thus preserving the humorous effect in the dialogue.

The second category comprises examples constituting a more complex group. It includes multiplex instances of cultural humour which cannot be pertained to as either low-problematic to translate (bumps) or untranslatable (clashes). That is why they can be referred to as "hurdles" - requiring a lot more effort, but in the end not impossible to translate. Those examples are usually construed on two different levels: one containing the cultural reference and the other purely linguistic, based usually on a wordplay, double entendre or choice of words in the context of the current situation. Due to their intricacy and problematic nature, the translation of such examples constitutes an often impassable challenge for the translator, resulting frequently in translation losses. In episode twenty of the fifth season, the group is holding a dinner in Leonard and Sheldon's apartment. The day of Bernadette and Howard's wedding approaches and since Raj did not return his RSVP, he asks him whether he decided if he was going alone or with someone.

S05E20

Raj: I'm coming and I'm bringing somebody. Koothrappali plus one.

Leonard: Who are you bringing?

Raj: Who are you bringing?

Penny: He's bringing me. Who are you bringing?

Raj: $\quad$ Wow, what a bunch of Nosey O'Donnells.

The complexity of this example results from merging a cultural concept and a wordplay. On the cultural level it is a reference to two people: Rosie O'Donnell, a popular comedian, actress and host of a daytime television talk-show that aired from 1996 to 2002 in the United States, and Aloysius "Nosey" Parker from the British television series Thunderbirds from the 1960s - a fictional character of a butler/chauffer helping his employer in espionage activities, who earned his nickname "Nosey" due to both his protruding nose and his nosiness (Aloysius 
Parker, n.d.). On the linguistic level, it plays on the word "nosey" (also written as "nosy") which rhymes with the name of Rosie O'Donnell, basing on a common nickname "nosy Rosie". This multilayered combination creates a humorous effect. Since it is extremely difficult, or nearly impossible, to create an analogous blend in Polish, a sensible translation choice would be to preserve either the cultural reference or the linguistic play-on-words. Cultural substitution comes in handy once more. By employing the name of Ewa Drzyzga, a famous Polish journalist and television presenter hosting her own talk-show Rozmowy w toku since 2000, as a substitute to Rosie O'Donnell, the cultural character of the utterance can be preserved. Nevertheless, the reference to source culture and the linguistic layer of the utterance is entirely lost. In such circumstances, it is troublesome, to say the least, to decide if "Nosie O'Donnell" can be referred to as translatable or untranslatable.

Culture clashes, in turn, can be described as those instances of cultural humour that are so intrinsic to and rooted in the source culture but, at the same time, entirely exotic to the target culture, that their translation is essentially impossible. They are not only absent from, but also not recognisable by the target culture, thus producing a "clash" in the understanding of a particular utterance in its original form among the target audience. The two cultures thus clash in such a way that the translator is left bereft of any viable translation solution. Whatever technique he used, the cultural reference would be utterly lost. Those instances of cultural humour are extremely problematic from the translational point of view, their rendition hardly ever resulting in the preservation of the cultural aspect in the humorous utterance since when left with "culture or humour" choice, the translator of a humorous text should always opt for the latter. In episode sixteen of the fourth season, Amy and Penny, the latter being Leonard's ex-girlfriend, discuss his present Indian girlfriend, Priya.

\section{S04E16}

Amy: Well, granted, Penny, your secondary sexual characteristics are reasonably bodacious... but Priya is highly educated, she's an accomplished professional... and she comes from the culture that literally wrote the book on neat ways to have sex. Whereas you, on the other hand, are a community college dropout... who comes from the culture that wrote the book on tipping cows.

The cultural concept in this example is highly rooted in the culture of rural America. Penny is here a representative dweller of the state of Nebraska - economically dependent on its agriculture, composed mostly of rural areas and associated with 
a poor level of education. The Nebraskans are thus often stereotyped by other Americans as indulging in such past-times as cow tipping. The term refers to a popular American urban legend purporting that the inhabitants of rural areas, due to the lack of other forms of entertainment, often approach an unsuspecting cow and tip it for fun so that it cannot regain an upward position. Although it is physically impossible for one person to tip a cow and that form of entertainment is just a myth, the stereotype persists (Swearingen: 2013). When juxtaposed with Indian culture, viewed as rich and artistic, the concept becomes even more humorous than it is on its own. Since the concept does not exist in the Polish culture, no official equivalent exists as well. There is also no other rural stereotypical pastime so widespread within the target culture that could make it possible to use substitution. Both cultures thus clash in such a way that the only reasonable option left for the translator is direct translation, generalisation or a paraphrase. Whatever the technique, the transfer of the cultural reference is impossible. The loss is inevitable, yet the humorous utterance in the dialogue could easily be preserved by the translator, which is the ultimate goal in translation of cultural humour and this is the course the translator should opt for when faced with "culture clashes".

\section{CONCLUSION}

The present article attempted at providing a rather rare perspective on the classification of such translation problems as culture-bound concepts. It brings into focus the position held by the translator in the translation process and illustrates possible gradation of such translation problems, having in mind the prospective result of translating a given source culture reference into the target language. Utterances which served as examples for this article are the instances of cultural humour, since humour is considered to be highly embedded in cultural context. As the position of culture in translation studies is still a focal point of discussions among linguists, a short review of the phenomenon known as "cultural shift" was provided, along with the discussion of the relationship between culture and language from different perspectives offered by translation scholars. The gradation attempt, in turn, stems from the vehement debate over the question of translatability and, by extension, potential untranslatability of culture. Although categorising such translation challenges as cultural references or cultural humour is difficult, the boundaries between the categories being blurred and not at all absolute, the proposed categorisation will hopefully give an even better insight into the process of translation, as it takes the translator's perspective into account and makes his effort and its ultimate result crucial to the translation process. 


\section{BIBLIOGRAFIA}

Aloysius Parker, (n.d.), [in:] Wikipedia, [in:] http://en.wikipedia.org/wiki/Aloysius_Parker [dostęp: 21.04.2016]

Bałuk-Ulewiczowa T., 2000, Beyond Cognizance: Fields of Absolute Untranslatability, [in:] W. Kubiński, O. Kubińska, T. Z. Wolański (red.), Przekładając nieprzekładalne, Gdańsk, s. $173-182$.

Bałuk-Ulewiczowa T., 2002, Dzieje innych miłości, czyli o nieprzekładalności bezwzględnej w tekstach o wartościach w sztuce, [in:] W. Chłopicki (red.), Język trzeciego tysiaclecia II, 2: Polszczyzna a języki obce: przektad i dydaktyka, „Język a komunikacja 4”, Kraków, s. 9-17.

Bassnett S., 2007, Culture and Translation, [in:] P. Kuhiwczak, K. Littau (eds.), A Companion to Translation Studies, Clevedon-Buffalo-Toronto, s. 13-23.

Bellis M., n.d., Famous Trademarks - Pillsbury Doughboy, About.com, [in:] http://inventors.about. com/od/pstartinventions/a/Pillsbury_Dough.htm [dostęp: 25.04.2016].

Catford J. C., 1965, A linguistic theory of translation, Oxford.

Cui J., 2012, Untranslatability and the Method of Compensation, "Theory and Practice in Language Studies", nr 2(4), s. 826-830, [in:] http:/ojs.academypublisher.com/index.php/tpls/article/ view/tpls0204826830/4574 [dostęp: 21.04.2016]; doi:10.4304/tpls.2.4.826-830.

Cymbalista P., 2003, Untranslatability as Culture-Specific Phenomenon, "Studia Anglica Resoviensia", nr 2(14), s. 21-31, [in:] http://www.ur.edu.pl/file/1251/sar_v2_02.pdf [dostęp: 23.04.2016].

Hatim B. \& Mason I., 1989, Discourse and the Translator, London.

Hejwowski K., 2004, Translation: A cognitive-communicative approach, Olecko.

Karamanian A. P., 2002, Translation and Culture, "Translation Journal”, nr 6(1), [in:] http://www. bokorlang.com/journal/19culture2.htm [dostęp: 25.04.2016].

Korzeniowska A., Kuhiwczak P., 1998, Successful Polish-English translation: tricks of the trade, Warszawa.

Kostovčík L., 2009, The Translation of Verbally-Expressed Humour on Screen in Slovakia: An Outline of Research Problems, [in:] Language, Literature and Culture in a Changing Transatlantic World, s. 175-180, [in:] www.pulib.sk/elpub2/FF/Ferencik2/pdf_doc/23.pdf [dostęp: 21.04.2016].

Lambert J., 2000, Cultural studies, the study of cultures and the question of language: facing / excluding the new millennium, [in:] D. Delabastita, L. D'hulst, R. Meylaerts (red.), 2006, Functional Approaches to Culture and Translation, Amsterdam/Philadelphia, s. 163-171.

Leemets T., 1992, Translating the "untranslatable" words, [in:] Euralex '92 - Proceedings, [in:] http://www.euralex.org/elx_proceedings/Euralex1992_2/022_Helle\%20Leemets\%20-Translating\%20the\%20untranslatable\%20words.pdf [dostęp: 17.04.2016].

Lefevere A. (red.), 1992, Translation: History, Culture: A Source Book, London-New York.

Lorre Ch. \& Prady B. (Producers) \& Cendrowski M. (Director). (2007-2012). Teoria wielkiego podrywu [DVD]. Seasons 1-5. United States: Warner Bros. Entertainment. Polish distribution: Galapagos Sp. z o.o.

Newmark P., 1988, A Textbook of Translation, London.

Nida E., Taber C., 1969, The Theory and Practice of Translation, Leiden.

Nosy, n.d., [in:] Oxford Dictionaries Online, [in:] http://www.oxforddictionaries.com/definition/ english/nosy?q=nosey [dostęp: 25.04.2016].

Pedersen J., 2005, How is culture rendered in subtitles?, [in:] MuTra Conference Proceedings, [in:] http://euroconferences.info/proceedings/2005_Proceedings/2005_Pedersen_Jan.pdf [dostęp: 22.04.2016].

Pisarska A., Tomaszkiewicz T., 1996, Współczesne tendencje przekładoznawcze, Poznań. 
Raphaelson-West D., 1989, On the Feasibility and Strategies of Translating Humor, "Meta", nr 34(1), s. 128-141, doi: 10.7202/003913ar.

Samuel M. B., Samuel K. D., 2007, Critical Approaches to the Notion of Translatability and Untranslatability of Texts in Translation Studies, "Pakistan Journal of Social Sciences", nr 4(3), s. 375-379, [in:] http://docsdrive.com/pdfs/medwelljournals/pjssci/2007/375-379.pdf [dostęp: 17.04.2016].

Swearinge J., 2013, Cow Tipping: Fake or Really Fake?, "Modern Farmer", [in:] http://modernfarmer.com/2013/09/cow-tipping-myth-or-bullcrap/ [dostęp: 07.04.2016].

Tisgam K. H., 2009, Translating Cultural Humour: Theory and Practice, "Wasit Journal for Humanities" 5(9), s. 79-121, [in:] http:/www.iasj.net/iasj?func=fulltext\&aId=19938 [dostęp: 21.04.2016].

\section{STRESZCZENIE}

Celem niniejszego artykułu jest zwrócenie uwagi na raczej rzadko spotykane podejście do tłumaczenia pojęć zakorzenionych w kulturze. Jest on próbą gradacji występowania nieprzetłumaczalności kulturowej w tekście źródłowym z perspektywy tłumacza poprzez wykorzystanie kilku przykładów humorystycznych kulturowo wypowiedzi z amerykańskiego serialu Teoria wielkiego podrywu. Początkową część jakże istotnej sekcji teoretycznej artykułu stanowi dyskusja na temat pozycji kultury w teorii thumaczenia, odwołująca się do zjawiska „zwrotu kulturowego” z lat 80. XX wieku oraz poruszająca temat związku między językiem i kulturą, wymieniając jednocześnie główne techniki tłumaczenia pojęć kulturowych. Jako że kultura może być często odzwierciedlona w humorze, dalsza część rozpatruje jego odmiany i podejścia do thumaczenia humoru. Trzecia część tej sekcji stanowi dyskusję na temat pojęcia nieprzetłumaczalności. Przedstawia rozważania dotyczące podziału nieprzetłumaczalności na językową i kulturową oraz jego celowości w świetle debaty w studiach językoznawczych o związku języka i kultury. Oferuje ona również wgląd w podejścia do nieprzetłumaczalności, prowadząc do dyskusji na temat nieprzetłumaczalności bezwzględnej oraz/lub jej gradacji. Na podstawie powyższego końcowa sekcja proponuje próbę gradacji przypadków nieprzetłumaczalności na podstawie humoru kulturowego w serialu Teoria wielkiego podrywu. Przez prezentację trzech przykładów z serialu rozdział wprowadza trzy kategorie wyrażeń (nie)przetłumaczalnych: culture bumps - wyboje kulturowe, complex linguistic hurdles - złożone językowe przeszkody oraz culture clashes - zderzenia kultur.

Słowa klucze: pojęcia związane z kulturą, humor, nieprzetłumaczalność kulturowa, wyboje kulturowe, złożone językowe przeszkody, zderzenia kultur

\section{SUMMARY}

The purpose of the present article is to direct attention to a rather infrequent perspective on translating culturally-embedded concepts. It constitutes an attempt to grade the instances of cultural untranslatability in a source text from translator's perspective by employing as examples a few culturally humorous utterances from the American TV series The Big Bang Theory. In the initial part of the substantial theoretical section the article launches into the discussion over the position of culture in translation theory, recalling the "cultural turn" of the 1980s and touching upon the relationship between language and culture, while also enumerating the prevalent techniques for translating culture-bound concepts. Since culture can often be reflected in humour, the ensuing part investigates its varieties and approaches to humour in translation. The third part of the section is a discussion over the concept of untranslatability. It ponders upon the dichotomy into linguistic and 
cultural untranslatability and its purposefulness in the light of the language-culture debate in linguistic studies. It also offers an insight into approaches to untranslatability, leading to the discussion over its absoluteness and/or gradability. Based on the foregoing, the latter section offers an attempt at grading the instances of untranslatability on the basis of culture-bound humour from The Big Bang Theory TV series. By presenting three examples from the series, the chapter introduces three categories of (un)translatable utterances: culture bumps, complex linguistic hurdles and culture clashes.

Keywords: culture-bound concepts, humour, cultural untranslatability, culture bumps, complex linguistic hurdle, culture clashes 